\title{
PENGEMBANGAN PERANGKAT PEMBELAJARAN TEMATIK-INTEGRATIF BERBASIS SOSIOKULTURAL DI SEKOLAH DASAR
}

\author{
Muhammad Abduh \\ Universitas Negeri Yogyakarta \\ Email: abdmuh90@gmail.com
}

\begin{abstract}
Abstrak
Penelitian ini bertujuan untuk menghasilkan perangkat pembelajaran tematikintegratif berbasis sosiokultural dengan tema indahnya kebersamaan yang layak dan efektif bagi peserta didik kelas IV SDN Pujokusuman 1 Yogyakarta. Jenis penelitian ini adalah penelitian pengembangan atau Research and Development $(R \mathcal{E} D)$. Tahap penelitian pengembangan ini mengacu pada model pengembangan Borg and Gall yang telah dielaborasi oleh Sukmadinata menjadi tiga kelompok, yaitu: (1) studi pendahuluan, (2) pengembangan, dan (3) pengujian dan sosialisasi. Subjek uji pendahuluan adalah tiga orang validator ahli dan satu orang validator praktisi. Subjek uji utama adalah peserta didik kelas IV B SDN Pujokusuman 1 Yogyakarta yang berjumlah 29 peserta didik. Hasil penelitian pada uji terbatas adalah produk silabus, RPP, media pembelajaran, bahan ajar, dan tes hasil belajar menurut validator ahli dan validator praktisi adalah layak untuk digunakan, dibuktikan dengan rerata skor Aiken's V untuk masing-masing perangkat pembelajaran yang mendekati 1, Uji efektivitas menggunakan desain eksperimen beforeafter dengan data hasil pre-test dan post-test menunjukkan perbedaan yang signifikan. Signifikansi yang dihasilkan dari perhitungan SPSS menunjukkan angka 0,0001 $\leq$ 0,05. Kegiatan guru sebelum dan ketika menggunakan perangkat yang dikembangkan mengalami peningkatan sebesar 34,26\%. Kegiatan peserta didik sebelum dan ketika diterapkan perangkat yang dikembangkan mengalami peningkatan sebesar 38,89\%.
\end{abstract}

Kata kunci: perangkat pembelajaran, tematik-integratif, dan basis sosiokultural

\section{THE DEVELOPMENT OF SOCIOCULTURAL-BASED THEMATIC-INTEGRATIVE LEARNING MEDIA IN ELEMENTARY SCHOOL}

\begin{abstract}
This study aims to produce the integrated thematic learning instruments based on sosioculture on the theme "indahnya kebersamaan" that is eligible effective for the fourth grade students of SDN Pujokusuman 1 Yogyakarta. This study was a research and development $(R \& D)$ based on Borg and Gall models that was ellaborated by Sukmadinata into three groups: (1) preliminary studies, (2) development, and (3) testing and socializaton. The subjects of limited test are three expert validators and one person practicioner validator. The subjects of main test are 29 fourth grade students of SDN Pujokusuman 1 Yogyakarta. The research finding reveals that the learning instruments in terms of the syllabus, lesson plan, learning media, teaching materials, and achievement test according to the experts are feasible to use, indicated by a mean score of Aiken's $V$ for each learning instrument that is approaching 1. Effectiveness testing that used before-after experimental design with the pre-test and post-test result shows a significant difference. The significance resulting from the calculation of SPSS shows the number $0.0001 \leq 0.05$. Teacher activities before and when using the products increased by $34.25 \%$. Students activities before and when the products were applied increased by $38.89 \%$.
\end{abstract}

Keywords: learning instruments, thematic integrated, and sosiocultural based 


\section{PENDAHULUAN}

Penerapan Kurikulum Tingkat Satuan Pendidikan (KTSP) masih terdapat beberapa permasalahan, salah satunya adalah kurikulum ini tidak mengakomodasi pergeseran paradigma pembelajaran abad 21. Paradigma teaching telah bergeser menjadi paradigma learning (Hidayat, 2013:122). Paradigma belajar abad sebelumnya lebih ditekankan pada paradigma teaching yaitu guru sebagai pusat belajar. Paradigma belajar pada abad 21 adalah paradigma learning, yaitu siswa yang menjadi pusat dalam proses pembelajaran. Paradigma ini menekankan bahwa guru tidak lagi menjadi satu-satunya sumber belajar, dan peranannya telah bergeser sebagai fasilitator belajar. Sebagai fasilitator belajar, guru dituntut untuk lebih kreatif dan inovatif dalam melaksanakan pembelajaran.

Permasalahan pergeseran paradigma pembelajaran ini dijawab oleh pemerintah dengan menyusun Kurikulum 2013 (K-13). Melalui K-13, pemerintah menyempurnakan pola pikir terhadap proses pendidikan selama ini. Pola pikir yang disempurnakan pemerintah menjawab kekurangan-kekurangan KTSP dan pergeseran paradigma pendidikan abad 21. Penyempurnaan pola pikir melalui K-13 yang diutarakan pemerintah, diharapkan dapat diikuti pula dengan perubahan pola pikir (mindset) para praktisi pendidikan, khususnya guru.

Sejalan dengan pendapat Nursisto (2014:10) yang menyatakan bahwa dengan K-13 guru diharapkan dapat mengubah mindset kinerjanya. Setidaknya ada tiga hal perubahan yanag harus dilakukan oleh guru terkait dengan K-13, hal pertama adalah merubah total pola belajar dari guru memberi tahu menjadi siswa yang mencari tahu. Secara prinsip guru tidak lagi hanya berceramah di depan kelas, namun guru bertindak sebagai fasilitator, motivator dan starter jalannya pembelajaran di kelas. Guru diharapkan dapat membangkitkan rasa ingin tahu siswa, sehingga siswa dapat mengembangkan potensi yang dimilikinya. Pada akhirnya siswa akan terangsang untuk mengembangkan materi yang bahkan melebihi materi ajar yang telah dipersiapkan oleh guru (Nursisto, 2014:12).

Selanjutnya yang harus diperhatikan guru adalah adanya pendekatan santifik. Menurut Kemdikbud (2013) yang termasuk pendekatan saintifik dalam kegiatan pembelajaan yaitu mengamati, menanya, menalar, mencoba dan membentuk jejaring. Aplikasi pembelajaran menggunakan pendekatan saintifik menurut Nursisto (2014:12) adalah: (1) siswa dirangsang dengan peragaan atau dihidupkan aktivitas inderanya, (2) siswa diarahkan agar penasaran untuk bertanya, (3) bersambung saling keterkaitan banyaknya pertanyaan itu menjadikan siswa tergugah ingin menggali lebih dalam tentang inti masalahnya, (4) sesuatu kesimpulan yang dengan pasti sudah didapatkan melalui tiga tahapan itu akhirnya ingin diperluas, dikroscek dengan berbagai sumber lain seperti buku ajar, bahan pustaka, surat kabar, internet, narasumber dan sumber lain dan akhirnya (5) sejumlah kesimpulan hasil dari apa yang telah secara berjenjang dilakukan siswa di bawah kendali guru itu dikomunikasikan dalam bentuk laporan, baik lisan maupun tulis, presentasi diskusi atau cara lain. Pendekatan saintifik diharapkan akan melatih siswa untuk berpikir secara ilmiah, dengan langkahlangkah ilmiah untuk menemukan atau membuktikan suatu pengetahuan serta peserta didik mampu mengembangkan kompetensi yang sesuai dengan Standar Kompetensi Lulusan (SKL).

SKL menurut Permendikbud No. 65 Tahun 2013 dalam kegiatan inti pembelajaran setidaknya mencakup tiga kompetensi. Kompetensi pertama adalah mengenai sikap, yang terdiri dari proses menerima, menjalankan, menghargai, menghayati, hingga mengamalkan. Kompetensi kedua adalah mengenai pengetahuan, yang da- 
pat dimiliki melalui aktivitas mengetahui, memahami, menerapkan, menganalisis, mengevaluasi, hingga mencipta. Kompetensi ketiga adalah mengenai keterampilan, yang diperoleh melalui kegiatan mengamati, menanya, mencoba, menalar, menyaji dan mencipta (Kemdikbud, 2013: 3). Ketiga kompetensi tersebut menuntut peserta didik untuk melakukan interaksi dengan lingkungannya, baik lingkungan kelas, sekolah, rumah, maupun lingkungan masyarakat.

Berdasarkan karakteristik K-13 yang menyebutkan pentingnya interaksi dan lingkungan masyarakat sebagai sumber belajar, maka diharapkan guru dapat mengintegrasikan aspek sosiokultural ke dalam proses pembelajaran. Berkaitan dengan sosiokultural, Vygotsky dalam Schunk (2008:243) berpendapat bahwa belajar membangkitkan berbagai proses perkembangan internal yang mampu beroperasi hanya ketika anak berinteraksi dengan orang-orang di lingkungannya dan bekerja sama dengan orang lain. Teori ini secara langsung menyebutkan bahwa dalam proses pembelajaran, anak tidak dapat terlepas dari lingkungan sosial dan orang-orang yang ada disekitarnya. Vygotsky menekankan pada pentingnya hubungan antara individu dan lingkungan sosial dalam pembentukan pengetahuan. Dengan kata lain interaksi sosial, yaitu interaksi individu tersebut dengan orang lain merupakan faktor terpenting yang dapat memicu perkembangan kognitif seseorang. Proses belajar akan terjadi secara efisien dan efektif apabila anak belajar secara kooperatif dengan anak-anak lain dalam suasana dan lingkungan yang mendukung, dalam bimbingan seseorang yang lebih mampu, guru atau orang dewasa. Maka dapat disimpulkan bahwa anakanak akan lebih mudah dalam memproses informasi dan menyusun pengetahuan ketika mereka berinteraksi langsung dengan lingkungan sosialnya.
Sejalan dengan pendapat Santrock (2012: 251) yang menyatakan bahwa anakanak menyusun pemikiran dan pemahamannya terutama melalui interaksi sosial. Perkembangan kognitif anak tergantung pada perangkat yang disediakan oleh lingkungan, dan pikiran mereka dibentuk oleh konteks kultural di tempat mereka tinggal. Lingkungan sosial mempengaruhi kognitif anak melalui sebuah alat atau perangkat, yaitu objek-objek kultural, seperti mobil, tulisan-tulisan di jalan, bangunan, dan bahasa serta institusi sosial mereka, seperti sekolahan, tempat ibadah, dan lain-lain. Interaksi sosial membantu mengkoordinasikan ketiga pengaruh tersebut pada perkembangan kognitif anak. Interaksi sosial dapat terjadi antara peserta didik dengan peserta didik, peserta didik dengan guru, maupun peserta didik dengan lingkungannya.

Guru adalah salah satu bagian terpenting dalam lingkungan sosial anak, terutama ketika mereka berada di sekolah. Guru diharapkan dapat menerapkan K-13 ke dalam proses pembelajaran di kelas, agar tujuan Pendidikan Nasional dapat tercapai. Menurut Suyanto (2013: 7) guru merupakan unsur terpenting dari pemangku kepentingan pendidikan dalam konteks implementasi K-13. Sebagai unsur terpenting dari implementasi K-13, guru diharapkan mampu merubah pendekatan pengajaran. Menurut Suyanto (2013: 7) pendekatan pengajaran pada Kurikulum 2013 ini mengalami perubahan yang sangat signifkan, yaitu dari pendekatan bidang studi beralih ke pendekatan tematik-integratif. Tentu saja guru harus bekerja ekstra untuk membiasakan diri menerapkan pendekatan tematik-integratif dengan perlahan-lahan meninggalkan pendekatan bidang studi. Oleh karena itu diperlukan seperangkat alat pembelajaran yang dapat membantu guru dalam memahami dan menerapkan K-13.

Salah satu perangkat pembelajaran yang dibutuhkan dalam pembelajaran 
adalah adanya Rancangan Pelaksanaan Pembelajaran (RPP). RPP yang digunakan dalam K-13 berbeda dengan RPP yang digunakan dalam KTSP. Perbedaan yang pertama kali terlihat adalah tidak adanya Standar Kompetensi (SK) di dalam penjabaran Kompetensi Dasar (KD) K-13. SK tidak hilang begitu saja, namun digantikan dengan Kompetensi Inti (KI). KI adalah gambaran mengenai kompetensi utama yang dikelompokkan ke dalam aspek sikap, pengetahuan, dan ketrampilan (afektif, kognitif, dan psikomotor) yang harus dipelajari peserta didik untuk suatu jenjang sekolah, kelas dan tema (Kemendikbud, 2013). Penjabaran KI dapat ditemukan pada silabus yang telah disusun Pemerintah, dari silabus tersebut diharapkan Guru dapat mengembangkan RPP untuk pembelajaran.

Menurut Permendikbud No. 65 Tahun 2013, Kompetensi Inti merupakan gambaran secara kategorial mengenai kompetensi dalam aspek sikap, pengetahuan, dan keterampilan yang harus dipelajari peserta didik untuk suatu jenjang sekolah, kelas dan mata pelajaran. Kompetensi Inti dirancang dalam empat hal yang saling terkait yaitu berkenaan dengan sikap keagamaan (kompetensi inti 1), sikap sosial (kompetensi 2), pengetahuan (kompetensi inti 3), dan keterampilan (kompetensi 4). Keempat kelompok itu menjadi acuan dari Kompetensi Dasar (KD) dan harus dikembangkan dalam setiap peristiwa pembelajaran secara integratif.

Penilaian pembelajaran pada Kurikulum 2013 menggunakan penilaian autentik (Authentic Assessment). Menurut Permendikbud No. 65 Tahun 2013, penilaian autentik adalah penilaian yang menilai kesiapan siswa, proses, dan hasil belajar secara utuh. Keterpaduan penilaian ketiga komponen tersebut akan menggambarkan kapasitas, gaya, dan perolehan belajar siswa atau bahkan mampu menghasilkan dampak instruksional dan dampak pengiring dari pembelajaran. Hasil penilaian otentik dapat digunakan oleh guru untuk merencanakan program perbaikan, pengayaan, atau pelayanan konseling. Selain itu, hasil penilaian otentik dapat digunakansebagai bahan untuk memperbaiki proses pembelajaran sesuai dengan Standar Penilaian Pendidikan (Permendikbud No. 65 tahun 2013). Dalam penilaian ini, guru dapat mengembangkan instrument penilaiannya, yang digunakan untuk menilai aktivitas peserta didik yang berupa aspek sikap, pengetahuan dan ketrampilan. Dari hasil penilaian autentik tersebut, diharapkan guru akan mendapat gambaran yang sebenarnya mengenai kondisi pembelajaran yang telah dilakukan. Gambaran yang didapatkan guru setelah melakuan penilaian autentik dapat berupa: (1) mengetahui bagaimana menilai kekuatan dan kelemahan peserta didik serta desain pembelajaran, (2) mengetahui bagaimana cara membimbing peserta didik untuk mengembangkan pengetahuan mereka sebelumnya dengan cara mengajukan pertanyaan dan menyediakan sumber daya memadai bagi peserta didik untuk melakukan akuisisi pengetahuan.

Sekolah Dasar (SD) Negeri Pujokusuman 1 Yogyakarta merupakan salah satu SD di Daerah Istimewa Yogyakarta (DIY) yang dijadikan pilot project implementasi Kurikulum 2013 oleh Kemdikbud. Hasil Wawancara dengan Guru Kelas IV pada hari Senin, 3 Maret 2014 menunjukkan bahwa perangkat pembelajaran yang sesuai dengan K-13 termasuk yang berbasis sosiokultural belum sepenuhnya dikembangkan oleh guru. Hasil studi awal penelitian, guru kelas IV di SD tersebut belum mengembangkan perangkat pembelajaran tersebut. Guru hanya mengikuti instruksiinstruksi yang terdapat pada buku pegangan guru dan pegangan siswa.

Pemahaman guru mengenai Kurikulum 2013 di SDN Pujokusuman 1 Yogyakarta masih tergolong rendah. Guru memahami bahwa dalam melaksankan Kurikulum 2013 hanya perlu menerapkan 
materi-materi yang terdapat di dalam buku pegangan guru dan siswa. Selain itu, guru beranggapan bahwa dalam K-13 materi yang perlu disampaikan lebih sedikit daripada kurikulum sebelumnya (KTSP). Padahal inti dari K-13 bukan hanya aspek pengetahuan saja. Aspek pengetahuan pada tingkat SD memang lebih sedikit dari pada aspek sikap.

Selain itu, dari hasil analisis kebutuhan, guru masih banyak berorientasi terhadap aspek pengetahuan dalam menerapkan K-13 (knowledge oriented), sehingga nilai-nilai sikap sosial dan budaya belum terintegrasikan di dalam pembelajaran. Berdasarkan gagasan Permendikbud No. 67 Tahun 2013 dapat diartikan bahwa pembelajaran yang menggunakan K-13 tidak dapat terlepas dari unsur sosial dan budaya Indonesia.

Faktor kultural disesuaikan dengan letak geografis sekolah dan peserta didik. Dalam hal ini, faktor sosiokultural yang sesuai dengan SDN Pujokusuman 1 adalah Yogyakarta. Yogyakarta memiliki beberapa nilai budaya yang telah disebutkan di dalam Peraturan Pemerintah No.04 Tahun 2011 tentang Tata Nilai Budaya. Peraturan Pemerintah DIY No. 04 Tahun 2011 tentang Tata Nilai Budaya menyebutkan bahwa tata nilai budaya Yogyakarta yang harus dilestarikan meliputi: (1) tata nilai religius spiritual; (2) tata nilai moral; (3) tata nilai kemasyarakatan; (4) tata nilai adat dan tradisi; (5) tata nilai pendidikan dan pengetahuan; (6) tata nilai teknologi; (7) tata nilai penataan ruang dan arsitektur; (8) tata nilai mata pencaharian; (9) tata nilai kesenian; (10) tata nilai bahasa; (11) tata nilai benda cagar budaya dan kawasan cagar budaya; (12) tata nilai kepemimpinan dan pemerintahan, dan (13) tata nilai semangat Yogyakarta.

Berdasarkan hasil need analysis di atas, dapat diketahui bahwa guru kesulitan mengembangkan perangkat pembelajaran tematik-integratif dan guru juga membutuhkan perangkat tersebut sehingga peneliti bermaksud melakukan penelitian pengembangan ini. Perangkat pembelajaran tematik-integratif yang dikembangkan mengacu pada nilai-nilai sosial budaya yang terdapat di Daerah Yogyakarta. Perangkat pembelajaran akan dikembangkan pada Kelas IV SDN Pujokusuman 1 Yogyakarta dengan subtema Keberagaman Budaya Bangsaku.

\section{METODE}

Berdasarkan masalah dan tujuan, penelitian ini dirancang dalam bentuk penelitian pengembangan (Research and Development/ R\&D). Gall, Gall \& Borg (2003: 570) mengungkapkan ada sepuluh langkah pelaksanaan penelitian dan pengembangan. Langkah-langkah itu adalah sebagai berikut: (1) mengumpulkan informasi dan melakukan penelitian awal (research and information collecting); (2) perencanaan (planning); (3) mengembangkan produk awal (developing preliminary form of product); (4) uji coba awal (preliminary field testing; (5) melakukan revisi terhadap tes berdasarkan hasil uji coba awal (main product revision); (6) melakukan uji lapangan utama (main field testing); (7) melakukan revisi setelah mendapatkan masukan dari uji lapangan utama (operational product revision); (8) melakukan uji operasional lapangan (operational field testing); (9) melakukan revisi terakhir produk (final product revision), dan (10) mendesiminasi dan mengimplementasikan produk (desimination and implementation).

Desain uji coba yang dilakukan bertujuan untuk menyempurnakan perangkat pembelajaran yang dikembangkan dengan mempraktekkannya secara langsung di lapangan dan mengetahui keefektifan dari produk. Uji coba yang dilakukan meliputi tiga tahap, yaitu uji pendahuluan, uji utama dan pengujian dan sosioalisasi. Uji pendahuluan dilakukan oleh ahli, praktisi dan rekan sejawat (expert judgement). Uji utama dilakukan pembelajaran pada satu kelas peserta didik menggunakan desain before after. 
Subjek coba dalam uji pendahuluan adalah tiga orang validator ahli yang berkompeten di dalam pembelajaran tematik-integratif dan K-13, dan satu orang guru kelas IV sebagai validator praktisi. Pada uji utama dan uji efektivitas, subyeknya adalah peserta didik kelas IV A SD N Pujokusuman Yogyakarta dengan jumlah 29 anak.

Instrumen pengumpulan data pada penelitian ini digunakan untuk mengumpulkan data pada tahap uji pendahuluan dan uji utama. Instrumen yang digunakan dalam penelitian dan pengembangan ini adalah pedoman wawancara, lembar penilaian kelayakan perangkat pembelajaran, dan lembar observasi kegiatan guru dan peserta didik.Validasi perangkat pembelajaran melibatkan dua validator ahli, dan satu validator praktisi. Lembar validasi yang digunakan adalah lembar penilaian silabus, lembar penilaian Rencana Pelaksanaan Pembelajaran (RPP), lembar penilaian media pembelajaran, lembar penilaian bahan ajar, dan lembar penilaian soal pretest dan posttest.

Data kualitatif dari hasil wawancara, komentar dan saran dari validator ahli dan validator praktisi, serta dari hasil observasi, selanjutnya dianalisis secara deskriptif untuk merevisi dan memperbaiki produk yang dikembangkan. Data kuantitatif berupa skor penilaian validator ahli, validator praktisi, dan instrumen soal tes, dianalisis dengan langkah: (1) tabulasi semua data yang diperoleh dari validator untuk setiap komponen dan butir penilaian yang tersedia dalam instrumen penilaian, (2) menghitung content validity coefficient menggunakan formula Aiken's V yang didasarkan pada hasil penilaian dari validator ahli sebanyak $n$ orang terhadap suatu item. Penilaian dilakukan dengan cara memberikan angka antara 1 (sangat tidak relevan) sampai dengan 5 (sangat relevan) (Azwar, 2013: 113).

\section{HASIL DAN PEMBAHASAN \\ Hasil Pengembangan}

Pengembangan perangkat pembelajaran tematik-integratif berbasis sosiokultural ini dilakukan dengan metode research and development (R\&D). Model pengembangan diadaptasi dari model pengembangan Borg and Gall yang telah dielaborasi oleh Sukmadinata menjadi tiga tahap, yaitu: 1) studi pendahuluan, 2) pengembangan, dan 3) pengujian dan sosialisasi. Penilaian produk awal oleh ahli (expert judgement) dilakukan dengan cara melakukan penilaian terhadap produk perangkat pembelajaran tematik-integratif yang dikembangkan menggunakan lembar penilaian yang telah dibuat. Perangkat pembelajaran dinilai oleh validator ahli, dan validator praktisi. Validasi oleh ahli dan praktisi dilakukan untuk memperoleh data kelayakan perangkat pembelajaran yang dikembangkan. Validasi juga bertujuan untuk menggali komentar dan saran, baik secara tertulis maupun lisan dengan cara berdiskusi tentang perangkat pembelajaran yang dikembangkan. Kegiatan validasi dilakukan dengan cara memberikan naskah perangkat pembelajaran (silabus, RPP, media pembelajaran, dan bahan ajar dan tes hasil belajar) berserta lembar penilaian kepada dua validator ahli, dan satu validator praktisi.

\section{Hasil Uji Coba Produk}

Penilaian produk awal oleh ahli (expert judgement) dilakukan dengan cara melakukan penilaian terhadap produk perangkat pembelajaran tematik-integratif yang dikembangkan menggunakan lembar penilaian yang telah dibuat. Perangkat pembelajaran dinilai oleh validator ahli, dan validator praktisi. Validasi oleh ahli dan praktisi dilakukan untuk memperoleh data kelayakan perangkat pembelajaran yang dikembangkan. Validasi juga bertujuan untuk menggali komentar dan saran, baik secara tertulis maupun lisan dengan cara berdiskusi tentang perangkat pembe- 
lajaran yang dikembangkan. Kegiatan validasi dilakukan dengan cara memberikan naskah perangkat pembelajaran (silabus, RPP, media pembelajaran, dan bahan ajar dan tes hasil belajar) berserta lembar penilaian kepada dua validator ahli, dan satu validator praktisi.

Hasil penilaian validator tersebut kemudian dinilai tingkat relevansi antar validator dengan menggunakan statistik Aiken's V pada setiap butirnya. Rentang skor $\mathrm{V}$ yang dapat diperoleh adalah antara 0 sampai dengan 1 (Azwar, 2013:133). Skor Aiken's V yang didapatkan untuk masing-masing butir pada penilaian silabus mendekati 1, maka dapat disimpulkan bahwa perangkat silabus memiliki validitas yang sangat tinggi dan layak digunakan. Perhitungan statistik Aiken's V untuk perangkat silabus disajikan melalui Gambar 1.

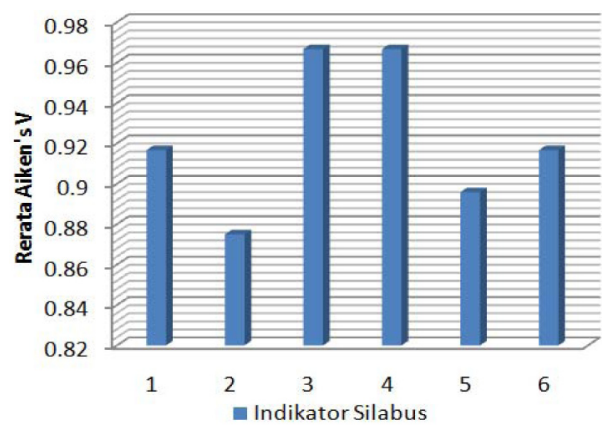

Gambar 1. Diagram Aiken's V untuk produk silabus

Hasil penilaian validator terhadap perangkat RPP kemudian dinilai tingkat relevansi antar validator dengan menggunakan statistik Aiken's V pada setiap butirnya. Rentang skor V yang dapat diperoleh adalah antara 0 sampai dengan 1 (Azwar, 2013:133). Skor Aiken's V yang didapatkan untuk masing-masing butir pada penilaian RPP mendekati 1, maka dapat disimpulkan bahwa perangkat RPP memiliki validitas yang sangat tinggi dan layak digunakan. Perhitungan statistik Aiken's V untuk perangkat RPP disajikan melalui Gambar 2.

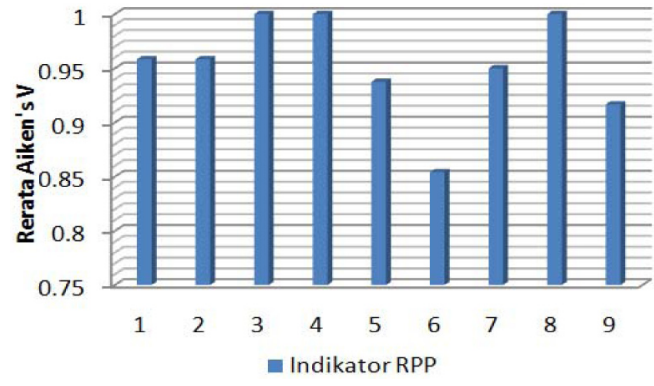

Gambar 2. Diagram Aiken's V produk RPP

Hasil penilaian validator terhadap perangkat media pembelajaran dinilai tingkat relevansi antar validator dengan menggunakan statistik Aiken's V pada setiap butirnya. Rentang skor V yang dapat diperoleh adalah antara 0 sampai dengan 1 (Azwar, 2013:133). Skor Aiken's V yang didapatkan untuk masing-masing butir pada penilaian media pembelajaran mendekati 1, maka dapat disimpulkan bahwa perangkat media pembelajaran memiliki validitas yang sangat tinggi dan layak digunakan. Perhitungan statistik Aiken's V untuk perangkat media pembelajaran disajikan melalui Gambar 3.

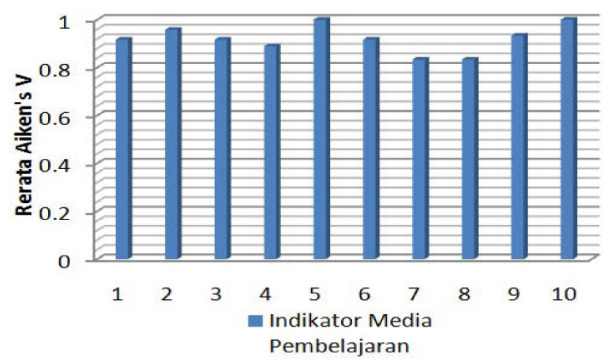

Gambar 3. Diagram Aiken's V produk media pembelajaran

Hasil penilaian validator terhadap perangkat bahan ajar dinilai tingkat relevansi antar validator dengan menggunakan statistik Aiken's V pada setiap butirnya. Rentang skor $\mathrm{V}$ yang dapat diperoleh adalah antara 0 sampai dengan 1 (Azwar, 2013:133). Skor Aiken's V yang didapatkan untuk masing-masing butir pada penilaian bahan ajar mendekati 1, maka dapat 
disimpulkan bahwa perangkat bahan ajar memiliki validitas yang sangat tinggi dan layak digunakan. Perhitungan statistik Aiken's V untuk perangkat bahan ajar disajikan melalui Gambar 4 berikut.

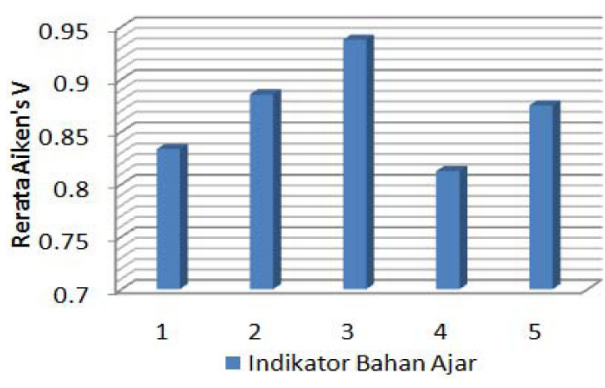

Gambar 4. Diagram Aiken's V produk bahan ajar

Hasil penilaian validator terhadap perangkat soal pretest dan postest kemudian dinilai tingkat relevansi antar validator dengan menggunakan statistik Aiken's V pada setiap butirnya. Rentang skor $V$ yang dapat diperoleh adalah antara 0 sampai dengan 1 (Azwar, 2013:133). Skor Aiken's V yang didapatkan untuk masing-masing butir pada penilaian soal tes hasil belajar mendekati 1, maka dapat disimpulkan bahwa perangkat soal tes hasil belajar memiliki validitas yang sangat tinggi dan layak digunakan. Perhitungan statistik Aiken's V untuk perangkat soal pretes dan soal hasil belajar disajikan melalui Gambar 5 berikut.

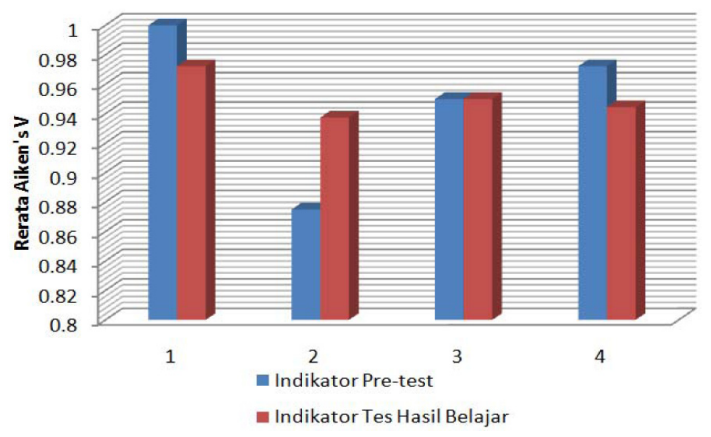

Gambar 5. Diagram Aiken's V produk soal pretes dan soal posttest

\section{Uji Coba Utama}

Uji coba utama bertujuan untuk mencari tahu keefektivan produk perangkat pembelajaran yang dikembangkan. Uji efektivitas dengan cara membandingkan hasil pretes dan tes hasil belajar setelah penggunaan produk yang telah divalidasi oleh validator. Selain menggunakan pretes dan tes hasil belajar, data yang digunakan adalah hasil observasi kegiatan guru dan peserta didik sebelum menggunakan produk perangkat pembelajaran, dan hasil observasi kegiatan guru dan peserta didik dalam menerapkan produk perangkat pembelajaran yang dikembangkan.

Sebelum guru menerapkan perangkat pembelajaran yang dikembangkan oleh peneliti, peserta didik mengerjakan soal pretes untuk mengetahui tingkat pemahaman awal peserta didik mengenai materi yang akan diajarkan. Setelah diterapkannya perangkat pembelajaran yang dikembangkan, maka peserta didik mengerjakan soal tes hasil belajar (postes), untuk mengetahui sejauh mana peserta didik memahami materi yang telah diajarkan. Selain untuk mengetahui tingkat pemahaman peserta didik, postes juga digunakan untuk mengetahui efektivitas produk yang dikembangkan.

Berdasarkan Tabel 1 tersebut, hasil pretest menunjukkan masih ada tujuh peserta didik yang belum mencapai Kriteria Ketuntasan Minimum (KKM), yaitu AFN, ZDM, RWF, YAP, AL, MF, dan RA. Sedangkan hasil posttest peserta didik dapat dilihat pada Tabel 2.

Batas Kriteria Ketuntasan Minimun (KKM) untuk individu adalah $\geq 70$, sedangkan persentase ketuntasan klasikal adalah $\geq 80 \%$ dari seluruh peserta didik. Berdasarkan Tabel 1, pada kegiatan pretes terdapat tujuh peserta didik yang tidak tuntas, dan persentase ketuntasan klasikal untuk pretest adalah $75,86 \%$. Hal tersebut menunjukkan bahwa nilai pre-test belum memenuhi persentase ketuntasan klasikal. 
Tabel 1. Hasil pretest Peserta Didik

\begin{tabular}{clll}
\hline No. & $\begin{array}{c}\text { Nama } \\
\text { Peserta } \\
\text { Didik }\end{array}$ & Pre-Test & $\begin{array}{l}\text { Ketuntasan } \\
\text { Pre-Test }\end{array}$ \\
\hline 1 & AFN & 65 & Tidak Tuntas \\
2 & AF & 70 & Tuntas \\
3 & AAN & 77 & Tuntas \\
4 & DBW & 76 & Tuntas \\
5 & KNF & 70 & Tuntas \\
6 & AAR & 80 & Tuntas \\
7 & VMP & 75 & Tuntas \\
8 & DV & 80 & Tuntas \\
9 & ICM & 70 & Tuntas \\
10 & JA & 77 & Tuntas \\
11 & FZ & 85 & Tuntas \\
12 & ZDM & 67 & Tidak Tuntas \\
13 & RRS & 80 & Tuntas \\
14 & RWF & 65 & Tidak Tuntas \\
15 & YAP & 60 & Tidak Tuntas \\
16 & AL & 67 & Tidak Tuntas \\
17 & DL & 85 & Tuntas \\
18 & DAP & 77 & Tuntas \\
19 & MF & 65 & Tidak Tuntas \\
20 & RO & 75 & Tuntas \\
21 & TS & 70 & Tuntas \\
22 & RA & 65 & Tidak Tuntas \\
23 & DZ & 80 & Tuntas \\
24 & SS & 77 & Tuntas \\
25 & PJ & 75 & Tuntas \\
26 & YD & 80 & Tuntas \\
27 & HF & 90 & Tuntas \\
28 & DR & 77 & Tuntas \\
29 & OV & 75 & Tuntas \\
\hline Ketuntasan & & $75,86 \%$ \\
Klasikal & & \\
\hline & & & \\
\hline
\end{tabular}

Selain itu, berdasarkan Tabel 2, untuk hasil pengerjaan soal THB terdapat tiga peserta didik yang tidak tuntas. Sedangkan persentase ketuntasan klasikal untuk THB adalah $89,65 \%$, yang berarti bahwa THB telah tuntas secara klasikal dan peningkatan persentase ketuntasan klasikal antara pre-test dan THB adalah sebesar 13,97\%. Nilai hasil pre-test dan THB peserta didik dapat dilihat pada Gambar 6.

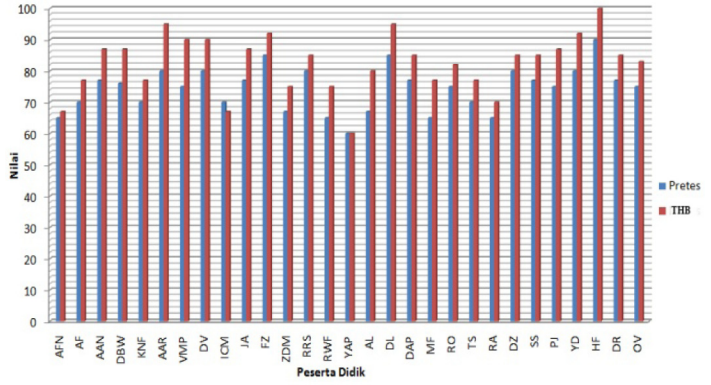

Gambar 6. Diagram perbandingan perolehan nilai pretes dan postes peserta didik

Tabel 2. Hasil Posttest Peserta Didik

\begin{tabular}{clll}
\hline No. & \multicolumn{1}{c}{$\begin{array}{c}\text { Nama } \\
\text { Peserta } \\
\text { Didik }\end{array}$} & $\begin{array}{c}\text { Tes Hasil } \\
\text { Belajar } \\
\text { (THB) }\end{array}$ & $\begin{array}{l}\text { Ketuntasan } \\
\text { THB }\end{array}$ \\
\hline 1 & AFN & 67 & Tidak Tuntas \\
2 & AF & 77 & Tuntas \\
3 & AAN & 87 & Tuntas \\
4 & DBW & 87 & Tuntas \\
5 & KNF & 77 & Tuntas \\
6 & AAR & 95 & Tuntas \\
7 & VMP & 90 & Tuntas \\
8 & DV & 90 & Tuntas \\
9 & ICM & 67 & Tidak Tuntas \\
10 & JA & 87 & Tuntas \\
11 & FZ & 92 & Tuntas \\
12 & ZDM & 75 & Tuntas \\
13 & RRS & 85 & Tuntas \\
14 & RWF & 75 & Tuntas \\
15 & YAP & 60 & Tidak Tuntas \\
16 & AL & 80 & Tuntas \\
17 & DL & 95 & Tuntas \\
018 & DAP & 85 & Tuntas \\
19 & MF & 77 & Tuntas \\
20 & RO & 82 & Tuntas \\
21 & TS & 77 & Tuntas \\
22 & RA & 70 & Tuntas \\
23 & DZ & 85 & Tuntas \\
24 & SS & 85 & Tuntas \\
25 & PJ & 87 & Tuntas \\
26 & YD & 92 & Tuntas \\
27 & HF & 100 & Tuntas \\
28 & DR & 85 & Tuntas \\
29 & OV & 83 & Tuntas \\
\hline Ketuntasan & & $89 \% 65 \%$ \\
Klasikal & & \\
\hline & & & \\
\hline
\end{tabular}

Untuk mengetahui efektivitas produk, maka nilai yang diperoleh masing-masing peserta didik, baik ketika pretes maupun postes diuji menggunakan uji-t sampel berpasangan. Uji-t sampel berpasangan 
ini menggunakan SPSS 16.0. Berdasarkan hasil perhitungan SPSS, didapatkan nilai sig. (2-tailed) adalah 0,0001 yaitu lebih kecil dari 0,05. Berdasarkan aturan statistik uji-t sampel berpasangan yang berlaku, jika nilai sig. (2-tailed) lebih kecil dari 0,05, maka Ho ditolak. Ho untuk hipotesis penelitian ini adalah "efektivitas perangkat pembelajaran baru lebih kecil atau sama dengan perangkat pembelajaran lama", karena Ho tersebut ditolak, maka hipotesis yang berlaku adalah Ha. Dengan demikian, maka efektivitas perangkat pembelajaran baru lebih baik dari perangkat pembelajaran lama. Dengan kata lain, perangkat pembelajaran tematik-integratif berbasis sosiokultural yang dikembangkan efektif untuk diterapkan.

Observasi dilakukan untuk mengetahui proses pembelajaran, baik pembelajaran sebelum menggunakan perangkat pembelajaran tematik-integratif berbasis sosiokultural, maupun pembelajaran ketika menggunakan perangkat pembelajaran tematik-integratif berbasis sosiokultural. Observasi dilakukan menggunakan instrumen berupa lembar observasi yang diisi oleh observer, yaitu Slamet Arifin,S. Pd selama enam hari.

\section{Observasi Guru Sebelum Menerapkan Produk}

Berdasarkan hasil pengamatan selama enam hari, pemahaman guru dalam menerapkan K-13 tergolong masih rendah. Rendahnya pemahaman guru terlihat oleh observer ketika mengamati proses pembelajaran. Pembelajaran saintifik yang menjadi ciri khas K-13 belum sepenuhnya nampak dalam proses pembelajaran. Guru masih mendominasi di dalam pembelajaran, sehingga peserta didik cenderung pasif.

Langkah-langkah pembelajaran saintifik yang seharusnya adalah mengamati, menanya, menalar, mencoba dan membentuk jejaring, belum semuanya nampak. Peserta didik hanya sampai pada tahap mengamati dan menanya. Kedua tahap inipun diterapkan guru hanya secara verbal, metode ceramah masih sangat mendominasi, sehingga tahap menalar, mencoba, dan membentuk jejaring belum dialami oleh peserta didik. Materi yang disampaikan guru secara verbal hanyalah sebatas materi yang terdapat di dalam buku pegangan guru dan peserta didik.

Penyampaian materi oleh guru tidak disertai dari sumber-sumber lain yang relevan, semisal dari buku lain ataupun dari internet. Oleh karena itu, guru belum membuat dan menyiapkan media pembelajaran yang mendukung proses pembelajaran. Guru cenderung kurang kreatif dan inovatif dalam menerapkan Kurikulum 2013. Padahal, di dalam kelas sudah tersedia fasilitas lcd proyektor, dan guru juga memiliki sebuah laptop. Fasiltas tersebut seharusnya dapat menjadi media pembelajaran yang efektif jika guru mampu dan mau mengembangkan media pembelajaran melalui fasilitas tersebut. Tanpa adanya media pembelajaran yang inovatif, maka proses pembelajaran di kelas menjadi terkesan menjenuhkan dan dapat berpengaruh terhadap peserta didik.

Selain itu, tanpa adanya media pembelajaran yang menarik, stimulus yang diberikan guru kepada peserta didik masih belum nampak. Kurangnya pemberian stimulus oleh guru, menyebabkan peserta didik pasif. Peserta didik kurang diberi kesempatan untuk bertanya dan terlibat aktif dalam pembelajaran.

Indikator selanjutnya yang menjadi perhatian observer adalah integrasi nilainilai sosiokultural dalam proses pembelajaran. Karena pemahaman guru mengenai K-13 yang masih rendah, guru kurang memperhatikan aspek sikap dan ketrampilan dalam pembelajaran. Hal ini menyebabkan guru belum mengintegrasikan nilai-nilai sosiokultural ke dalam proses pembelajaran, sehingga proses pembelajaran belum berbasis budaya. Padahal 
Yogyakarta merupakan daerah yang kental akan unsur budaya.

Berdasarkan fenomena-fenomena yang muncul dari hasil observasi tersebut, dapat ditarik kesimpulan bahwa pemahaman guru mengenai Kurikulum 2013 masih rendah. Hal ini berpengaruh terhadap proses pembelajaran di kelas. Guru belum bertindak sebagai fasilitator, dan pembelajaran belum berpusat kepada peserta didik. Hal ini menyebabkan rendahnya pelibatan aktif peserta didik di dalam pembelajaran. Pengaruh lainnya adalah guru belum mengintegrasikan aspek sikap, keterampilan dan unsur sosiokultural di dalam pembelajaran, sehingga pembelajaran masih terkesan sangat knowledge oriented.

Selama pengamatan berlangsung, observer menemukan beberap indikator yang layak untuk mendapatkan skor tinggi. Salah satu indikator tersebut adalah penggunaan bahasa Indonesia. Berdasarkan pengamatan observer, selama proses pembelajaran guru telah menggunakan bahasa Indonesia dengan baik dan benar. Penggunaan bahasa Indonesia menjadi keharusan bagi guru dan peserta didik dalam berkomunikasi saat proses pembelajaran. Namun terkadang guru juga menyelipkan kosakata berbahasa Jawa, hal ini terkadang efektif untuk menarik perhatian peserta didik yang mulai terlihat jenuh.

Indikator selanjutnya yang menunjukkan kelebihan guru adalah penguasaan materi pelajaran. Selama pengamatan berlangsung, observer tidak menyaksikan guru kesulitan dalam penguasaan materi pelajaran. Hal ini bisa disebabkan karena faktor pengalaman guru dalam mengajar.

Diagram rerata skor masing-masing indikator hasil observasi kegiatan guru sebelum menggunakan perangkat pembelajaran berbasis sosiokultural disajikan melalui gambar 17. Sedangkan hasil observasi kegiatan guru sebelum menggunakan perangkat pembelajaran berbasis sisokul- tural untuk setiap pertemuan ditampilkan pada gambar 18.

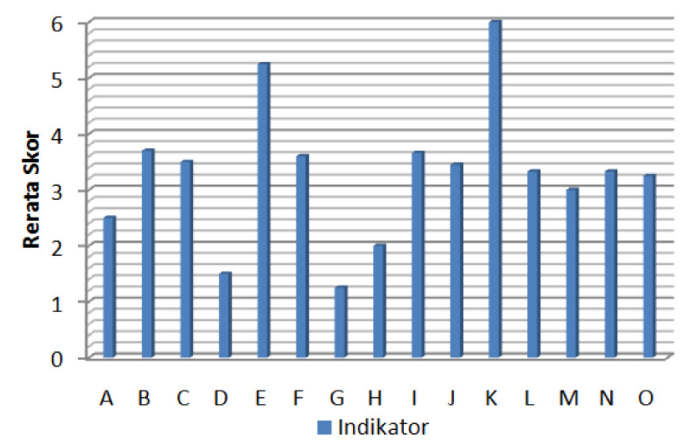

Gambar 7. Skor Rerata Masing-masing Indikator Hasil Observasi Kegiatan

Guru sebelum Menggunakan Perangkat Pembelajaran Berbasis Sosiokultural

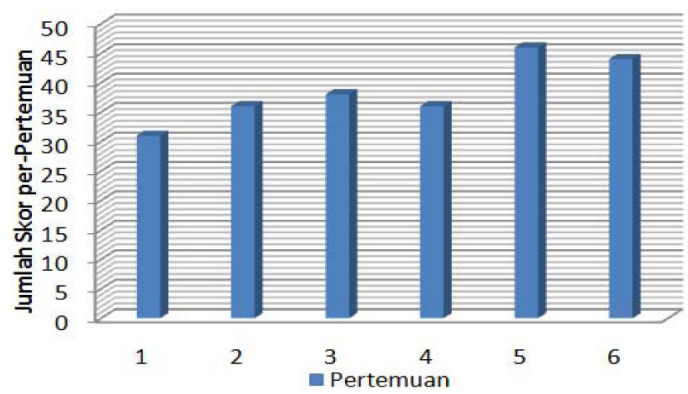

Gambar 8. Hasil Observasi Kegiatan Guru per Pertemuan Sebelum Menggunakan Perangkat Pembelajaran Berbasis Sosiokultural

Berdasarkan Gambar 7 pada observasi awal sebelum menggunakan perangkat pembelajaran tematik-integratif berbasis sosiokultural, guru belum sepenuhnya memahami penerapan Kurikulum 2013 dalam pembelajaran. Penerapan pembelajaran saintifik dan pengintegrasian nilai sosiokultural cenderung rendah. Berdasarkan gambar 8, skor hasil observasi untuk masing-masing pertemuan masih jauh dari skor maksimal yaitu 72 .

\section{Observasi Kegiatan Guru Ketika Mener- apkan Produk}

Observasi dilakukan selama enam hari, atau enam kali pertemuan. Selama observasi, observer mengamati kegiatan guru dalam proses pembelajaran di kelas, mulai 
dari awal kegiatan hingga akhir kegiatan pembelajaran. Observasi ini bertujuan untuk mengetahui proses pembelajaran ketika guru menggunakan perangkat pembelajaran tematik-integratif berbasis sosiokultural yang dikembangkan.

Observer menggunakan lembar observasi yang berisi 15 indikator sebagai pedoman dalam mengobservasi kegiatan guru. Salah satu indikator yang menjadi perhatian dalam observasi adalah mengenai penerapan pembelajaran saintifik. Kegiatan pembelajaran yang dilaksanakan guru mengikuti tahap-tahap pembelajaran pada perangkat pembelajaran tematikintegratif berbasis sosiokultural yang dikembangkan.

Berdasarkan pengamatan observer, terjadi peningkatan pemahaman guru terhadap K-13 ketika proses pembelajaran berlangsung. Hal ini terlihat dari segi penerapan pembelajaran saintifik. Guru menerapkan langkah-langkah pembelajaran saintifik secara utuh, yaitu mulai dari mengamati, menanya, menalar, mencoba dan membentuk jejaring. Guru memberi kesempatan peserta didik untuk menalar dan kemudian mencoba, selanjutnya membentuk jejaring dengan kegiatan presentasi dan diskusi.

Guru telah memahami bahwa dirinya adalah seorang fasilitator di dalam pembelajaran, sehingga pembelajaran telah berpusat kepada peserta didik. Guru menyampaikan fakta-fakta melalui media yang telah memanfaatkan lcd proyektor dan laptop, sehingga pembelajaran menjadi lebih menarik dan menyenangkan. Faktafakta yang disampaikan guru nantinya akan diamati oleh peserta didik. Guru memberikan kesempatan peserta didik untuk bertanya mengenai fakta yang telah dipaparkan tersebut. Selanjutnya guru memberi kesempatan peserta untuk mencoba dan membentuk jejaring.

Kegiatan mencoba dan membentuk jejaring mulai nampak pada seluruh kegiatan pembelajaran. Melalui kegiatan mencoba ini, guru mengintegrasikannya dengan nilai sosiokultural dan memperhatikan aspek sikap serta keterampilan peserta didik. Pembelajaran pada hari pertama, guru memberi kesempatan peserta didik untuk mencoba menyanyikan lagu "Aku Anak Indonesia", kemudian mendiskusikan makna dari lagu tersebut bersama kelompoknya untuk selanjutnya mempresentasikan hasil diskusi di depan kelas. Pada pembelajaran hari kedua, guru memberikan kesempatan peserta didik untuk mencoba mengukur sudut benda-benda yang ada di dalam kelas menggunakan busur derajat. Guru juga menggunakan gambar-gambar rumah adat untuk menstimulus peserta didik dan mengajak peserta didik dalam mempelajari jenis-jenis dan pengukuran sudut. Pertemuan selanjutnya, hingga pertemuan keenam, kegiatan mencoba tidak terlepas dari proses pembelajaran.

Kegiatan pembelajaran yang berlangsung tidak terlepas dari kegiatan tanya jawab, diskusi, melakukan percobaan, dan presentasi. Guru lebih aktif dalam menstimulus peserta didik untuk meningkatkan rasa ingin tahu mereka. Rasa ingin tahu tersebut dijadikan modal peserta didik untuk melakukan kegiatan diskusi dan kegiatan mencoba.

Stimulus yang diberikan oleh guru menggunakan media yang berbasis budaya, seperti gambar rumah adat, tarian adat, video tarian adat, video permainan tradisional, dan media berbasis budaya lainnya. Melalui perangkat pembelajaran tematik-integratif berbasis sosiokultural yang diterapkan ini, peserta didik akan lebih tertarik merespon, dan guru akan mudah mengajak peserta didik mempelajari materi pokok yang diajarkan.

Diagram skor rerata hasil observasi kegiatan guru ketika menerapkan perangkat pembelajaran tematik-integratif berbasis sosiokultural untuk masing-masing indikator dapat dilihat pada gambar 9 . Diagram skor hasil observasi kegiatan 
guru ketika menerapkan perangkat pembelajaran tematik-integratif berbasis sosiokultural untuk setiap pertemuan dapat dilihat pada gambar 10 .

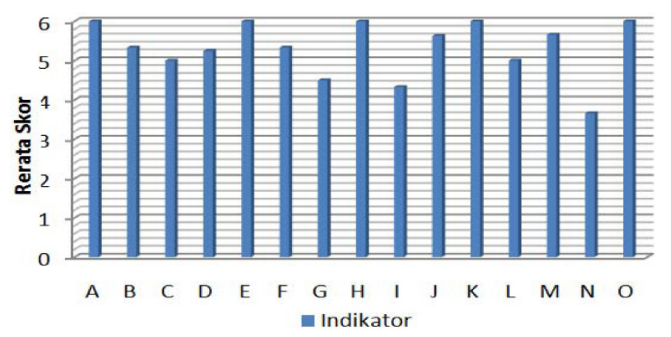

Gambar 9. Rerata Skor Masing-masing Indikator Hasil Observasi Kegiatan Guru Ketika Menggunakan Perangkat Pembelajaran Berbasis Sosiokultural

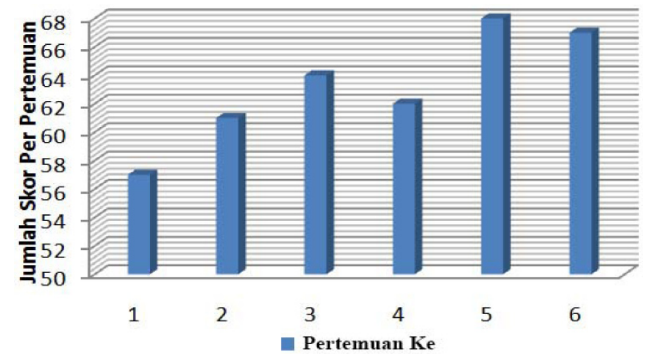

Gambar 10. Hasil Observasi Kegiatan Guru per-Pertemuan Ketika Memakai

Perangkat Pembelajaran Berbasis Sosiokultural

Berdasarkan hasil pengamatan observer, kegiatan guru ketika menggunakan perangkat pembelajaran tematik-integratif berbasis sosiokultural mengalami peningkatan signifikan. Perbandingan skor hasil pengamatan kegiatan guru sebelum dan ketika memakai produk untuk masingmasing indikator disajikan melalui gambar 11. Perbandingan skor hasil pengamatan kegiatan guru sebelum dan ketika memakai produk untuk setiap pertemuan disajikan melalui gambar 12.

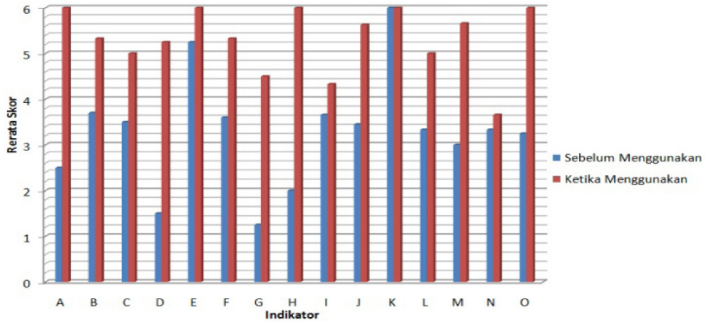

Gambar 11. Perbandingan skor rerata hasil pengamatan kegiatan guru untuk setiap indikator

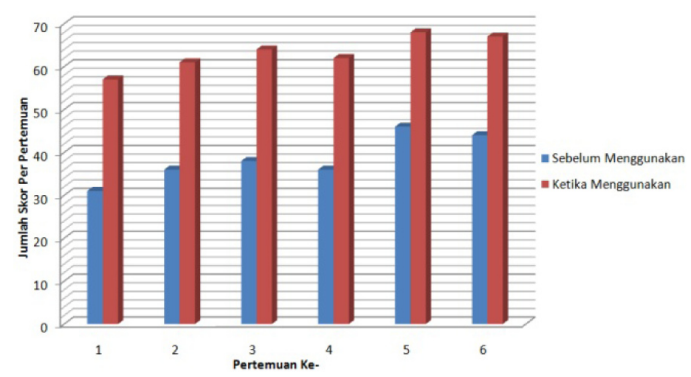

Gambar 12. Perbandingan skor hasil pengamatan kegiatan guru untuk setiap pertemuan

Berdasarkan gambar 11 dan 12, skor observasi kegiatan guru mengalami peningkatan yang signifikan antara sebelum dan ketika guru menggunakan perangkat pembelajaran tematik-integratif berbasis sosiokultural. Berdasarkan peningkatan skor observasi kegiatan guru yang signifikan ini dapat ditarik kesimpulan bahwa perangkat pembelajaran tematik-integratif berbasis sosiokultural yang dikembangkan memiliki efektivitas yang tinggi.

\section{Observasi Kegiatan Peserta Didik Sebe- lum Menerapkan Produk}

Observasi dilakukan selama enam hari, atau enam kali pertemuan. Selama observasi, observer mengamati kegiatan peserta didik dalam proses pembelajaran di kelas, mulai dari awal kegiatan hingga akhir kegiatan pembelajaran. Observasi ini bertujuan untuk mengetahui kondisi awal proses pembelajaran ketika belum menggunakan perangkat pembelajaran tematik-integratif berbasis sosiokultural 
yang dikembangkan.

Observer menggunakan lembar observasi yang berisi tiga indikator sebagai pedoman dalam mengobservasi kegiatan peserta didik. Indikator pertama adalah kegiatan individu peserta didik. Menurut hasil pengamatan, peserta didik belum diposisikan sebagai pusat pembelajaran, namun masih sebagai objek yang menerima materi dari guru dengan pasif. Berdasarkan pengamatan, hanya ada empat orang peserta didik yang aktif dalam merespon melalui menjawab maupun bertanya.

Masih banyak peserta didik yang belum memperhatikan guru ketika menyampaikan materi. Sehingga, ketika guru menyampaikan stimulus berupa pertanyaan, banyak dari peserta didik yang tidak bisa menjawab, meskipun ada beberapa namun jawabannya masih belum seperti harapan guru. Rendahnya perhatian peserta didik terhadap guru bisa dikarenakan guru belum menggunakan media pembelajaran yang dapat menarik perhatian peserta didik. Peserta didik cenderung jenuh dengan proses pembelajaran yang sedang berlangsung, sehingga mereka tidak sepenuhnya fokus mengikuti pembelajaran.

Selain perhatian peserta didik yang rendah, masih banyak peserta didik yang belum membuat catatan berupa materi yang dismapaikan guru maupun kesimpulan pembelajaran. Berdasarkan hasil pengamatan, peserta didik belum membuat catatan karena mereka masih bingung apa saja yang harus dicatat, karena mereka kurang memperhatikan. Meskipun sudah didikte oleh guru, masih banyak peserta didik yang membuat catatan dengan meminjam catatan teman lainnya.

Indikator selanjutnya adalah aktivitas peserta didik dengan kelompok. Selama enam hari pengamatan, setidaknya terdapat tiga kali pembelajaran yang menggunakan diskusi kelompok. Guru membagi siswa menjadi lima kelompok secara heterogen dari sisi jenis kelamin maupun ting- kat kognitif. Meskipun demikian peserta didik belum nampak aktif dalam kegiatan diskusi kelompok tersebut.

Keaktifan peserta didik di dalam kelompok belum merata. Dari lima atau enam anggota kelompok, hanya dua peserta didik saja yang aktif, sedangkan tiga atau empat anggota kelompok lainnya masih terlihat pasif. Banyaknya peserta didik yang masih pasif bisa dikarenakan mereka belum terbiasa dengan metode diskusi kelompok, selain itu stimulus yang diberikan guru juga kurang kuat, sehingga peserta didik lemah dalam merespon.

Rerata skor hasil observasi kegiatan peserta didik sebelum menggunakan perangkat pembelajaran tematik-integratif berbasis sosiokultural untuk tiap indikator disajikan pada gambar 13. Jumlah skor hasil observasi kegiatan peserta didik sebelum menggunakan perangkat pembelajaran tematik-integratif berbasis sosiokultural untuk tiap pertemuan disajikan pada Gambar 14.

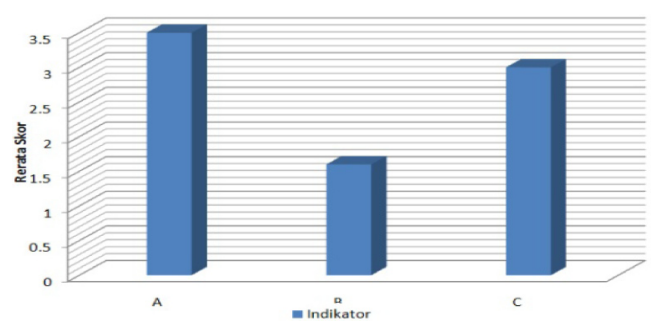

Gambar 13. Rerata Skor Masing-masing Indikator Hasil Observasi Kegiatan

Peserta Didik Sebelum Menggunakan Perangkat Pembelajaran Berbasis

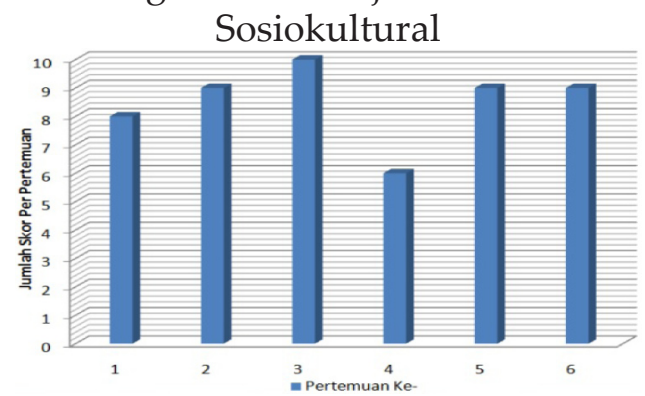

Gambar 14. Hasil Observasi Kegiatan Peserta Didik per Pertemuan Sebelum Menggunakan Perangkat Pembelajaran Berbasis Sosiokultural 
Berdasarkan Gambar 13 pada observasi awal sebelum menggunakan perangkat pembelajaran tematik-integratif berbasis sosiokultural, menunjukkan bahwa aktivitas peserta didik untuk masing-masing indikator masih tergolong rendah. Rendahnya aktivitas peserta didik juga terlihat pada gambar 14, skor hasil observasi kegiatan peserta didik untuk masing-masing pertemuan masih jauh dari skor maksimal yaitu 18.

\section{Observasi Kegiatan Peserta Didik Ketika Menerapkan Perangkat Pembelajaran Berbasis Sosiokultural}

Observasi dilakukan selama enam hari, atau enam kali pertemuan. Selama observasi, observer mengamati kegiatan peserta didik dalam proses pembelajaran di kelas, mulai dari awal kegiatan hingga akhir kegiatan pembelajaran. Observasi ini bertujuan untuk mengetahui proses pembelajaran ketika menggunakan perangkat pembelajaran tematik-integratif berbasis sosiokultural yang dikembangkan.

Observer menggunakan lembar observasi yang berisi tiga indikator sebagai pedoman dalam mengobservasi kegiatan peserta didik. Menurut pengamatan observer, banyak perubahan yang terjadi pada aktivitas peserta didik ketika diterapkan perangkat pembelajaran tematikintegratif berbasis sosiokultural. Peserta didik menjadi lebih aktif. Namun, masih banyak peserta didik yang mengganggu temannya ketika sedang mengerjakan tugas. Hal seperti ini memang sulit untuk diminimalisir, sebab guru masih kesulitan untuk mengendalikan masing-masing peserta didik yang berjumlah 29 anak. Guru tidak sepenuhnya membiarkan peserta didik mengganggu temannya, biasanya hukuman yang diberikan untuk peserta didik yang menggangu adalah membacakan hasil pekerjaannya di depan kelas, atau ditunjuk sebagai presenter mewakili kelompoknya.
Berdasarkan pengamatan observer, proses pembelajaran ketika menggunakan perangkat pembelajaran tematik-integratif berbasis sosiokultural lebih banyak kepada kegiatan diskusi kelompok. Diskusi kelompok yang berjalan menimbulkan adanya kegiatan peer teaching antar peserta didik di dalam kelompok tersebut. Peserta didik menjadi lebih aktif dalam kelompok ketika guru memberikan Lembar Kerja Peserta Didik (LKPD) yang mengharuskan didiskusikan secara berkelompok oleh peserta didik. Akibat positif lainnya adalah peserta didik menjadi lebih berani mengemukakan pendapat, dan bertanya kepada teman satu kelompoknya disaat mengerjakan LKPD.

Menurut pengamatan observer, peserta didik menjadi lebih aktif bertanya dan mencari tahu ketika guru menerapkan perangkat pembelajaran tematik-integratif berbasis sosiokultural. Pertanyaan peserta didik tidak hanya ditujukan kepada peserta didik lainnya, namun juga ditujukan kepada guru. Peserta didik menjadi lebih fokus terhadap materi dan informasi yang disampaikan guru melalui media pembelajaran berupa lcd proyektor. Selain guru menyampaikan materi dan informasi, guru juga menyampaikan beberapa stimulus yang membuat peserta didik mengajukan beberapa pertanyaan. Salah satu contoh, ketika guru menyampaikan materi perambatan bunyi melalui udara, guru bertanya suara apakah yang seringkali merambat melalui udara. Beberapa peserta didik menjawab suara halilintar atau petir. Kemudian guru menstimulus lagi dengan pertanyaan, ada yang pernah melihat halilintar atau petir, ada yang tahu apa itu halilintar atau petir. Karena stimulus dari guru ini, seorang peserta didik malah menanyakan proses terjadinya halilintar. Karena pertanyaan inilah, materi yang diajarkan menjadi berkembang lebih luas dan menambah wawasan peserta didik.

Rerata skor hasil observasi kegiatan peserta didik ketika menggunakan perangkat 
pembelajaran tematik-integratif berbasis sosiokultural untuk tiap indikator disajikan pada gambar 15. Jumlah skor hasil observasi kegiatanpeserta didik ketika menggunakan perangkat pembelajaran tematik-integratif berbasis sosiokultural untuk tiap pertemuan disajikan pada Gambar 16.

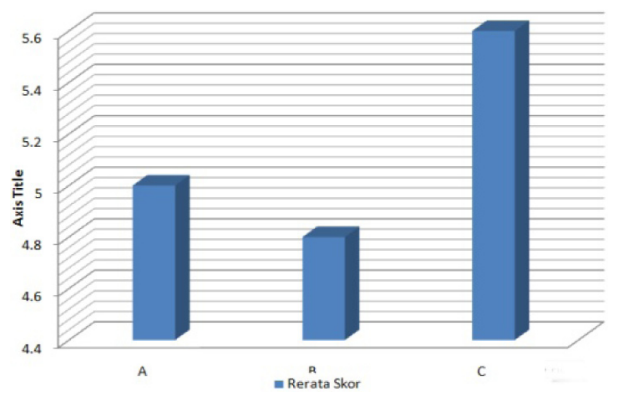

Gambar 15. Rerata Skor Masing-masing Indikator Hasil Observasi Kegiatan Peserta Didik Ketika Menggunakan Perangkat Pembelajaran Berbasis Sosiokultural

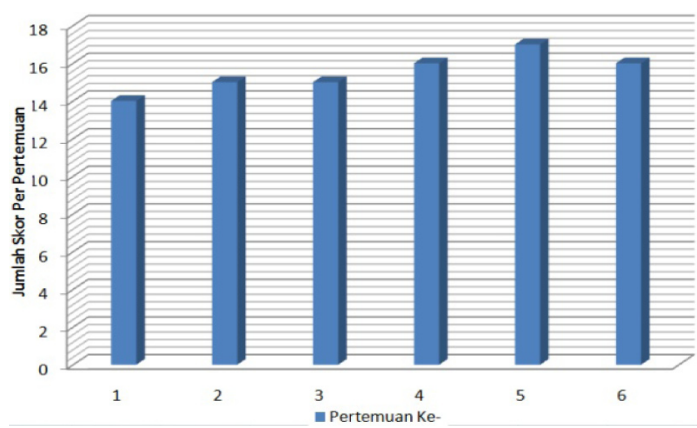

Gambar 16. Hasil Observasi Kegiatan Peserta Didik per Pertemuan Ketika Menggunakan Perangkat Pembelajaran Berbasis Sosiokultural

Perbandingan rerata skor hasil observasi kegiatan peserta didik sebelum dan ketika diterapkannya perangkat pembelajaran tematik-integratif berbasis sosiokultural untuk masing-masing indikator disajikan melalui Gambar 17. Sedangkan perbandingan skor hasil observasi kegiatan peserta didik sebelum dan ketika diterapkan perangkat pembelajaran tematik-integratif berbasis sosiokultural untuk masing-masing pertemuan disajikan melalui gambar 18.

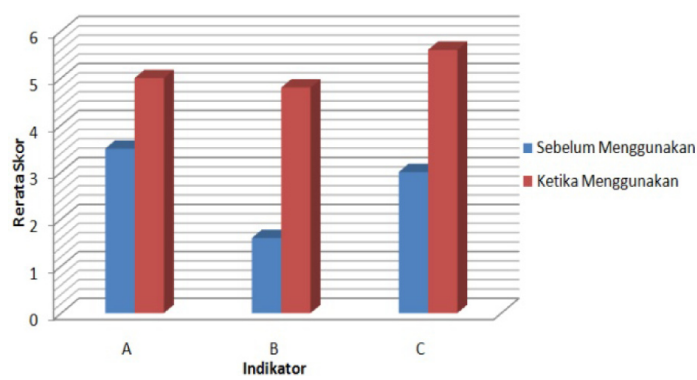

Gambar 17. Perbandingan skor rerata hasil pengamatan kegiatan peserta didik untuk setiap indikator

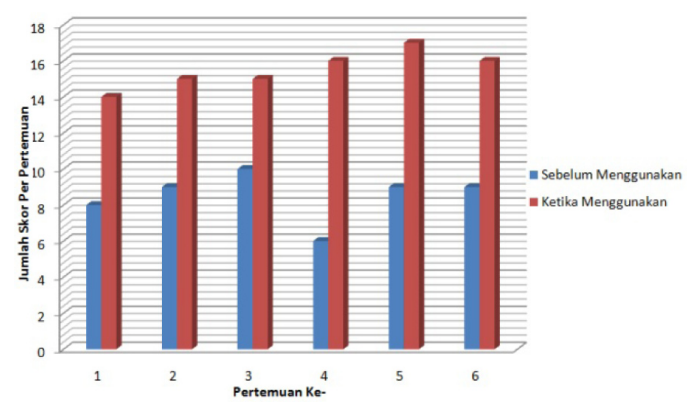

Gambar 18. Perbandingan skor hasil pengamatan kegiatan peserta didik untuk setiap pertemuan

Berdasarkan Gambar 17 dan 18, skor observasi kegiatan peserta didik mengalami peningkatan yang signifikan antara sebelum dan ketika penggunaan perangkat pembelajaran tematik-integratif berbasis sosiokultural. Berdasarkan peningkatan skor observasi kegiatan peserta didik yang signifikan ini dapat ditarik kesimpulan bahwa perangkat pembelajaran tematikintegratif berbasis sosiokultural yang dikembangkan memiliki efektivitas yang tinggi.

\section{PENUTUP}

Berdasarkan hasil penelitian dan hasil kajian produk, dapat disimpukan bahwa perangkat pembelajaran tematik-integratif pada sub tema keberagaman budaya bangsaku berbasis sosiokultural dikatakan layak untuk setiap komponen perang- 
kat adalah sebagai berikut: (1) Silabus tematik-integratif berbasis sosiokultural dikembangkan dengan mengintegrasikan nilai-nilai budaya pada kegiatan pembelajaran, menggunakan penilaian otentik, dan menggunakan sumber belajar yang ada disekitar peserta didik dan relevan dengan kebudayaan di lingkungan peserta didik. (2) RPP tematik-integratif berbasis sosiokultural dikembangkan dengan menggunakan pendekatan saintifik pada langkah-langkah pembelajaran, mengintegrasikan nilai-nilai budaya pada kegiatan pembelajaran, menumbuhkan interaksi sosial pada pelaksanaan pembelajaran, menggunakan penilaian otentik, menggunakan sumber belajar yang ada disekitar peserta didik dan relevan dengan kebudayaan di lingkungan peserta didik. (3) Media pembelajaran tematik-integratif berbasis sosiokultural dikembangkan menggunakan benda-benda yang ada disekitar peserta didik dan mengandung nilai budaya, permainan tradisional yang relevan dengan materi, dan menggunakan media yang mencakup kegiatan saintifik pada proses pembelajaran. (4) Bahan ajar tematik-integratif berbasis sosiokultural dikembangkan dengan mengitegrasikan nilai religi, sosial, dan budaya tradisional, serta mengakomodasi perkembangan kognitif peserta didik mulai dari $\mathrm{C} 1$ hingga C4. (5) Tes hasil belajar tematik-integratif berbasis sosiokultural dikembangkan melalui bentuk-bentuk pertanyaan/soal yang mencakup kegiatan saintifik, pertanyaan yang berkaitan dengan budaya peserta didik dan relevan dengan materi pelajaran.

Berdasarkan hasil kegiatan uji utama, dapat dinyatakan bahwa perangkat pembelajaran tematik-integratif berbasis sosiokultural efektif. Keefektivan perangkat pembelajaran dibuktikan dengan hasil pengolahan SPSS nilai pre-test dan tes hasil belajar peserta didik menggunakan paired sample t-test. Hasil pengolahan tersebut menunjukkan hasil signifikansi 0,0001 $\leq$ 0,005, dengan kata lain menunjukkan sig- nifikansi yang tinggi. Selain itu, persentase ketuntasan klasikan pre-test lebih rendah dibandingkan persentase ketuntasan klasikal tes hasil belajar. Persentasi ketuntasan klasikal tes hasil belajar mengalami kenaikan sebesar 13,97\%.

Adapun saran pemanfaatan perangkat pembelajaran tematik-integratif berbasis sosiokultural hasil pengembangan adalah sebagai berikut: (1) Perangkat pembelajaran tematik-integratif berbasis sosiokultural sudah diuji kelayakan dan keefektifannya, maka disarankan kepada guru untuk menggunakan perangkat ini sebagai alternatif pilihan dalam pembelajaran tematik-integratif di SD kelas IV agar proses belajar mengajar yang terjadi berbasis sosiokultural. (2) Informasi tentang keefektivan perangkat pembelajaran tematik-integratif berbasis sosiokultural masih sangat terbatas, maka terbuka peluang untuk peneliti yang lain untuk mengkaji lebih jauh tentang keefektivannya. (3) Perangkat pembelajaran sejenis dengan ini dapat dikembangkan lebih lanjut dengan sub tema yang berbeda serta sosiokultural yang berbeda.

\section{DAFTAR PUSTAKA}

Azwar, S. (2013). Reliabilitas dan Validitas. Yogyakarta: Pustaka Pelajar.

Gall, M.D., Gall, J.P., \& Borg, W.R. (2003). Educational Research An Introduction. Boston: Ablongman.

Hidayat, S. (2013). Pengembangan Kurikulum Baru. Bandung: Remaja Rosdakarya Offset.

Kementrian Pendidikan dan Kebudayan. (2013). Peraturan Menteri Pendidikan dan Kebudayaan Republik Indonesia Nomor 65, Tahun 2013, tentang Standar Proses Pendidikan dasar dan Menengah.

Kementrian Pendidikan dan Kebudayaan. (2013). Peraturan Menteri Pendidikan dan Kebudayaan Republik Indonesia Nomor 67, Tahun 2013, tentang Kerangka Dasar dan Struktur Kuri- 
kulum Sekolah Dasar/Madrasah Ibtidaiyah.

Nursisto. (2014). Kurikulum 2013 Tuntut Keuletan Guru. http://krjogja.com/. Diakses Tanggal 20 Januari 2014.

Santrock. (2012). Perkembangan Masa Hidup Edisi Ketigabelas, Jilid I. (Terjemahan Benedictine Widyasinta). Jakarta: Erlanga.
Schunk, D.H. (2008). Learning Theories an educational perspective ( $5^{\text {th }} e d$ ). New Jersey: Pearson.

Suyanto. (2013). Katup Pengaman Kurikulum 2013. Kompas, 8 Juli, hal 7. 